АВТЕНТИФІКАЦЦЯ РЕЗУЛЬТАТІВ РЕЙТИНГОВОЇ ОЦНКИ СТАНУ ЗАХВОРЮВАНОСТІ НАСЕЛЕННЯ НА ГІПЕРТОНІЧНУ ХВОРОБУ В КОНТЕКСТІ АДМІНІСТРАТИВНО-ТЕРИТОРІАЛЬНОГО ТА РЕГІОНАЛЬНОГО УСТРОЮ УКРӒ̈НИ

\title{
В.В. Рудень
}

Львівський національний медичний університет імені Данила Галицького, м. Львів, Україна

\begin{abstract}
Ключові слова: Україна, адміністративнотериторіальний устрій, область, регіон, населення, гіпертонічна хвороба, первинна та загальна захворюваність, рейтингова оцінка.

Буковинський медичний вісник. 2020. T.24, № 3 (95), C. 195-203.

DOI:

10.24061/2413-0737. XXIV.3.95.2020.93

E-mail:vruden@ukr.net

Резюме. Досліджені стан первинної та загальної захворюваності на усі форми гіпертонічної хвороби населення Украӥни в контексті наявного адміністративно-територіального та регіонального устрою Украӥни. Отримані результати, незважаючи на їх різноманітність та кількість, переконливо засвідчують про пряму загрозу иієї патології здоров'ю та життю мешканців України незалежно від території їх проживання, щзо вимагає на рівні держави нагальних і реальних та дієвих напрачювань та реалізачії шляхів профілактичного змісту щуодо вчасної мінімізації ризиків у виникненні та подальшому розвитку гіпертонічної хвороби в конкретної людини / громади / популяції.

Мета дослідження. Обгрунтування результатів рейтингової оцінки стану захворюваності населення на гіпертонічну хворобу в контексті адміністративно-територіального та регіонального устрою України. Матеріал $\boldsymbol{i}$ методи. Виконано епідеміологічне, одномоментне, суиільне, проспективне наукове дослідження, де проаналізовані біостатистичні дані МОЗ та Держаної служби статистики України (2002-2018) з їх зведенням та опраџюванням у електронних таблииях пакета Microsoft Office Excel 2016, при використанні низки наукових медико-статистичних методів дослідження з урахуванням принцииів системності.

Результати. Дані рейтингової очінки рівня поширеності гіпертонічноі хвороби серед населення на адміністративних територіях, незважаючи на його амплітуду в стані первинної ( $P_{\text {пер }}=2732,8 \%$ ооо у Миколаївській - перше та $P_{\text {пер}}=922,6 / 100$ тис. у Херсонській - n'яте місие) та загальної захворюваності (Pзал $=34335,8 \%$ ооо $y$ Дніпропетровській - перше та $P_{\text {заг }}=22541,1 / 100000$ у Харківській областях - n'яте місие) та результати такого рейтингу серед жителів регіонів, де Центральний регіон (Вінницька, Дніпропетровська, Кіровоградська, Полтавська, Черкаська, Хмельницька) з першим оціночним місием як у стані первинної ( $\sum n=191023 ; \quad P=28,0 \pm 1,6 \%$, при $\left.P=1810,3 / 100000\right)$, так $i$ загальної $\left(\sum n=2947296 ; \quad P=28,4 \pm 1,6 \% ; \quad P=29507,4 \%\right.$ \%ооо) захворюваності на гіпертонічну хворобу над усіма іншими регіональними територіями, переконливо засвідчує про пряму загрозу даної патології здоров'ю та життю мешканців України незалежно від території їх проживання.

Висновок. Отримані результати обтрунтовано засвідчують, що як первинна, так $i$ загальна захворюваність на гіпертонічну хворобу $\epsilon$ складною медико-соціальною проблемою серед населення України як в усіх адміністративних терироріях, так і регіонах країни, що потребує нагальних на рівні держави реальних та дієвих напращювань профілактичних иляхів вчасної мінімізачії ризиків у виникненні та подальшому розвитку гіпертонічної хвороби в конкретної людини / громади / популяиії, щя матиме позитивний $і$ безпосередній вплив на покращення стану громадського здоров'я населення та розвиток економіки України.
\end{abstract}


Проблеми охорони здоров'я

Ключевые слова:

Украина,

административно-

территориальное

устройство, область,

регион, население,

гипертоническая

болезнь, первичная $и$

общая заболеваемость, рейтинговая оценка.

Буковинский медииинский вестник. 2020. T.24, № 3 (95), C. 195-203.

\section{АВТЕНТИФИКАЦЦИЯ РЕЗУЛЬТАТОВ РЕЙТИНГОВОЙ ОЦЕНКИ СОСТОЯНИЯ ЗАБОЛЕВАЕМОСТИ НАСЕЛЕНИЯ ГИПЕРТОНИЧЕСКОЙ БОЛЕЗНЬЮ В КОНТЕКСТЕ АДМИНИСТРАТИВНО-ТЕРРИТОРИАЛЬНОГ И РЕГИОНАЛЬНОГО УСТРОЙСТВА УКРАИНЫ}

\section{B.В. Рудень}

Резюме. Исследованы состояние первичной и общей заболеваемости всеми формами гипертонической болезни населения Украины в контексте имеющегося административно-территориального $u$ регионального устройства страны.

Полученные результаты, несмотря на их разнообразие по числовым значениям, убедительно свидетельствуют о прямой угрозе данной патологии здоровью и жизни жителей Украиньл независимости от территории их прожсивания, что требует на уровне государства неотложных, реальных и действенных наработок по реализации путей профилактического содержания з иелью своевременной минимизации рисков в возникновении и дальнейшем развитии гипертонической болезни у конкретного человека / общества / популяции.

Цель исследования. Обоснование результатов рейтинговой оценки состояния заболеваемости населения гипертонической болезнью в контексте административно-территориального и регионального устройства Украины.

Материал и методы. Выполнено эпидемиологическое, одномоментное, сплошное, проспективное научное исследование, где проанализировань биостатистические данные Минздрава и Государственной службы статистики Украины (2002-2018) с их возведением и обработкой в электронных таблицах пакета Microsoft Office Excel 2016 nри использовании ряда научных медико-статистических методов исследования с учетом принципов системности.

Результаты. Данные рейтинговой оиенки уровня распространенности гипертонической болезни среди населения на административных территориях, несмотря на его амплитуду в состоянии первичной ( $P_{\text {пер }}$ $=2732,8^{\circ}$ оооо в Николаевской - первое и $P_{\text {пер }}=922,6 / 100 \mathrm{mblc} .6$ Херсонской - пятое место) и общей заболеваемости $\left(P_{\text {заг }}=34335,8^{\circ} \%\right.$ в Днепропетровской - первое и $P_{\text {заг }}=22541,1 / 100000$ в Харьковской областях - пятое место) и результаты такого же рейтинга среди жителей регионов, где Центральный регион (Винниикая, Днепропетровская , Кировоградская, Полтавская, Черкасская, Хмельницкая) с первым оценочным местом как в состоянии первичной ( $\Sigma n=191023 ; \quad P=28,0 \pm 1,6 \%$, при $P=1810,3 / 100000), \quad$ так и общей ( $\Sigma n=2947296 ; \quad P=28,4 \pm 1,6 \% ; \quad P=29507,4 \%$ оооо) $\quad$ заболеваемости гипертонической болезнью над всеми другими региональными территориями, убедительно свидетельствует о прямой угрозе данной патологии здоровью и жизни жителей Украинь независимо от территории их проживания.

Вывод. Полученные результаты свидетельствуют, что как первичная, так и общая заболеваемость гипертонической болезнью является сложной медико-соииальной проблемой среди населения Украины как во всех административных терирориях, так и регионах страны, что требует неотложных на уровне государства реальных и действенных наработок профилактических путей своевременной минимизации рисков в возникновении и дальнейтем развитии гипертонической 
Problems of medical care

болезни у конкретного человека / общества / популяции, что окажет положительное и непосредственное влияние на улучшение состояния общественного здоровья населения и развитие экономики Украины.

\begin{tabular}{ll}
\hline \hline Keywords: Ukraine, & AUTHENTICATION OF THE RATING ASSESSMENT RESULTS OF \\
administrative-territorial & THE HYPERTONIC DISEASE MORBIDITY STATE OF THE \\
structure, oblast, region, & POPULATION IN THE CONTEXT OF ADMINISTRATIVE- \\
population, hypertonic & TERRITORIAL AND REGIONAL STRUCTURE OF UKRAINE
\end{tabular}

disease, primary and general morbidity, rating assessment.

\section{V. Ruden}

Bukovinian Medical Herald. 2020. V.24, № 3 (95). P. 195-203.

Abstract. The state of primary and general morbidity of all forms of hypertonic disease among the population of Ukraine in the context of the existing administrative-territorial and regional structure of the state has been studied.

The obtained results, despite their differences in numerical terms, clearly demonstrate a direct threat of this pathology to the health and lives of residents of Ukraine, regardless of their residence area, that requires urgent, real and effective developments and implementation of ways of preventive content for timely minimization of risks in the occurrence and further development of hypertonic disease in a particular person / community / population at the state level.

Purpose of the study. A substantiation of the rating assessment results of the hypertonic disease morbidity state of the population in the context of the administrative-territorial and regional structure of Ukraine.

Material and methods. An epidemiological, cross-sectional, continuous, prospective scientific study was conducted, where the statistical data of the Ministry of Health and the State Statistics Service of Ukraine (2002-2018) were analyzed, summarized and processed in spreadsheets developed by Microsoft Office Excel 2016, using a number of scientific medical and statistical research methods, taking into account the systematic principles.

Results. Data on the rating assessment of the hypertonic disease morbidity prevalence level among the population in administrative territories, despite its amplitude in the state of primary $\left(P_{p r}=2732.8 \%\right.$ ooo in Mykolaiv Oblast the first and $P_{p r}=922.6 / 100$ thousand in Kherson Oblast - the fifth place) and general morbidity $\left(P_{\text {gen }}=34335.8 \%\right.$ oooo in Dnipropetrovsk Oblast - the first and $P_{\text {gen }}=22541.1 / 100000$ in Kharkiv Oblast - the fifth place) and the results of such rating among residents of regions, where the Central region (Vinnytsia Oblast, Dnipropetrovsk Oblast, Kirovohrad Oblast, Poltava Oblast, Cherkasy Oblast, Khmelnytskyi Oblast) with the first estimated place both in the state of the primary $\left(\sum n=191023 ; P=28.0 \pm 1.6 \%\right.$, with $P=1810.3 / 100000)$, and general $\left(\sum n=2947296 ; P=28.4 \pm 1.6 \% ; P=29507.4\right.$ $\%$ oooo) hypertonic disease morbidity over all other regional territories, clearly demonstrates the direct threat of this pathology to the health and life of the inhabitants of Ukraine, regardless of their territory of residence.

Conclusion. The obtained results substantiate that the primary and general hypertonic disease morbidity is a complex medical and social problem among the population of Ukraine in all administrative territories and regions of the country, which requires urgent, real and effective development of preventive ways to timely minimize the risks of occurrence and further development of hypertonic disease in a particular person / community / population at the state level, which will have a positive and direct impact on improving public health and economic development of Ukraine. 
Вступ. Наприкінці XX та на початку XXI сторіччя людство зіткнулося в стані громадського здоров'я 3 проблемою серцево-судинних захворювань [1], серед яких - гіпертонічна хвороба, яка за твердженнями ВОО3 та Міжнародного товариства 3 вивчення артеріальної гіпертонії $\epsilon$ «найбільшою в історії людства неінфекційною пандемією» [2] , що призводить до тяжких ускладнень [3], сприяє розвитку мозкового інсульту та ішемічної хвороби серця [4], котрі провокують непрацездатність, ранню інвалідність та передчасну смертність серед населення [5], в тому числі, і серед осіб працездатного віку.

Не винятком у цьому є гіпертонічна хвороба і серед населення України $[6,7]$.

Враховуючи складну епідемічну ситуацію 3 вельми підступним захворюванням для людини гіпертонічною хворобою в Україні [8], проведено вивчення істинної поширеності гіпертонічної хвороби серед населення як різних адміністративних територій держави, так і в контексті їі історико-географічних регіонів, що і робить дане досліджнення актуальним у власному змісті.

Мета дослідження. Обгрунтування результатів рейтингової оцінки стану захворюваності населення на гіпертонічну хворобу в контексті адміністративно-територіального та регіонального устрою України.

Матеріал і методи. Виконано епідеміологічне, одномоментне, суцільне, проспективне наукове дослідження 3 використання статистичних даних Держаної служби статистики України [9] Центру медичної статистики МО3 України [10] та зведенням їx i опрацюванням у електронних таблицях пакета Microsoft Office Excel 2016. Застосовано ретроспективний, біостатистичний, математичний, абстрактний та картографічний методи дослідження, а також методи викопіювання, дедуктивного освідомлення, рейтингової оцінки, структурно-логічного аналізу 3 урахуванням принципів системності.

Результати дослідження та їх обговорення. Аналіз отриманих даних рейтингової оцінки, у відповідності 3 отриманими показниками розповсюдження захворюваності всіма формами гіпертонічної хвороби серед населення в контексті наявного на сьогодні адміністративнотериторіального устрою країни [11], переконливо засвідчує, що перший оціночний ранг згідно зі встановленим критерієм - найвищий рівень $\left(\mathrm{P}_{\text {пер }}=2600-2999 \%\right.$ \%оо $)$ поширеності ГХ первинної захворюваності на гіпертонічну хворобу в 2017 році (картограма), характерним є для населення двох областей України $\left(\mathrm{P}_{\text {стр }}=7,4 \%\right)$, a саме: Миколаївської $\quad\left(\mathrm{P}_{\text {пер }}=2732,8 \quad \%\right.$ оооо $) \quad$ та Дніпропетровської ( $\mathrm{P}_{\text {пер }}=2630,1 / 100$ тис.).
Найвищі показники розповсюдження загальної захворюваності на ГХ, згідно зі встановленим критерієм ( $\mathrm{P}_{\text {заг }}=30000-49999 \%$ оооо $)$, властивими $є$ для населення чотирьох областей $\left(\mathrm{P}_{\text {стр }}=14,8 \%\right)$, поміж яких: Дніпропетровська ( $\mathrm{P}_{\text {заг }}=34335,8 / 100$ тис.), Хмельницька $\quad\left(\mathrm{P}_{\text {заг }}=32033,4 \%\right.$ оооо $), \quad$ Полтавська $\left(\mathrm{P}_{\text {заг }}=31027,4 \%\right.$ оооо $)$ та Миколаївська $\left(\mathrm{P}_{\text {заг }}=34335,8\right.$ $\%$ oоoo).

Визначено, що другий рівень - високий $\left(\mathrm{P}_{\text {пер }}=2100-2599 \%\right.$ оооо $)$, притаманний за показниками поширення первинної захворюваності на ГХ для жителів таких трьох адміністративних територій $\left(\mathrm{P}_{\text {стр }}=11,1 \%\right)$, як Донецької $\quad\left(\mathrm{P}_{\text {пер}}==2216,3 \%\right.$ \%ооо $)$; Хмельницької ( $\mathrm{P}_{\text {пер }}=2185,5 \%$ та $\%$ ІваноФранківської $\left(\mathrm{P}_{\text {пер }}==2169,6 \%\right.$ оооо $)$.

Аналогічний рівень - високий $\left(\mathrm{P}_{\text {заг }}=27000\right.$ $29999 \%$ оооо) за судженням є властивий і стану загальної розсіюваності досліджуваної хвороби [I10-I15; I20X7 -I25X7; I60;X7-I69X7] для мешканців шести областей та одного міста обласного значення $\left(\mathrm{P}_{\text {cтр }}=25,9 \%\right)$, серед яких Кіровоградська $\left(\mathrm{P}_{\text {заг }}=29158,2 \%\right.$ \%оо $)$, Житомирська $\left(\mathrm{P}_{\text {заг }}=28528 / 100 \quad\right.$ тис. $), \quad$ Чернівецька $\left(\mathrm{P}_{\text {заг }}=28082,8 \%\right.$ оооо $)$, Тернопільська $\left(\mathrm{P}_{\text {заг }}=27443,2 / 100\right.$ тис.), Київська ( $\mathrm{P}_{\text {заг }}=27351,5 \%$ оооо $)$ та Херсонська $\left(\mathrm{P}_{\text {заг }}=27184,6 / 100\right.$ тис. $)$, а також поміж жителів міста Києва $\left(\mathrm{P}_{3 а г}=27239,3 \%\right.$ оооо $)$.

Доведено, що під третій - середній рівень $\left(\mathrm{P}_{\text {пер }}=1600-2099 \%\right.$ \%ооо $)$ розповсюдження первинної захворюваності на гіпертонічну хворобу підпадають у досліджуваному році обивателів Одеської $\quad\left(\mathrm{P}_{\text {пер }}=1959,8\right.$ випадка гіпертонічної хвороби на 100 тисяч населення даного регіону), Львівської $\quad\left(\mathrm{P}_{\text {пер }}=1871,4 \%\right.$ оооо $), \quad$ Сумської $\left(\mathrm{P}_{\text {пер }}=1789,9 / 100 \quad\right.$ тис. $), \quad$ Закарпатської ( $\mathrm{P}_{\text {пер }}=1767,2 \%$ \%оо $), \quad$ Кіровоградської $\left(\mathrm{P}_{\text {пер }}=1695 / 100000\right)$, Чернігівської $\left(\mathrm{P}_{\text {пер }}=1682,8 \%\right.$ оооо $)$, Полтавської ( $\mathrm{P}_{\text {пер }}=1608,5 / 100$ тис. $), \quad$ Київської $\left(\mathrm{P}_{\text {пер }}=1600,3 \%\right.$ оооо $)$ областей та міста Києва $\left(\mathrm{P}_{\text {пер }}=1827,9 / 100000\right)$, що в структурі всієї вперше зареєстрованої досліджуваної патології [I10I15;I20X7-I25X7; I60;X7-I69X7] становить $\mathrm{P}_{\text {стр }}=33,3 \%$.

До третього оціночного рівня $\left(\mathrm{P}_{\text {заг }}=25000\right.$ $26999 \%$ оооо ) відносяться також і встановлені показники поширення загальної захворюваності всіма видами ГХ серед населення шести областей $\left(\mathrm{P}_{\text {стр }}=22,2 \%\right)$, а саме: Чернігівської $\left(\mathrm{P}_{\text {заг }}=26803,9\right.$ випадка ГХ на 100 тис. населення даної області),

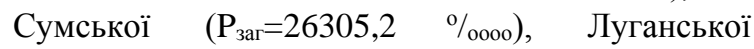
( $\mathrm{P}_{\text {заг }}=26144,9 / 100$ тис. $)$, Одеської $\left(\mathrm{P}_{\text {заг }}=25811,4 \%\right.$ оооо $)$, Івано-Франківської $\quad\left(\mathrm{P}_{\text {заг }}=25677,6 / 100000\right)$ та Черкаської ( $\mathrm{P}_{\text {заг }}=25541,1 \%$ оооо $)$.

Низький ступінь ( $\mathrm{P}_{\text {пер }}=1200-1599 \%$ \%ооо $)$ вперше виявлених випадків ГХ в Україні або четверте узагальнене місце, зареєстровано в $\mathrm{P}_{\text {стр }}=29,6 \%$ усіх облікованих випадків поміж жителів восьми таких адміністративних регіонів, як Тернопільської 


\section{Problems of medical care}
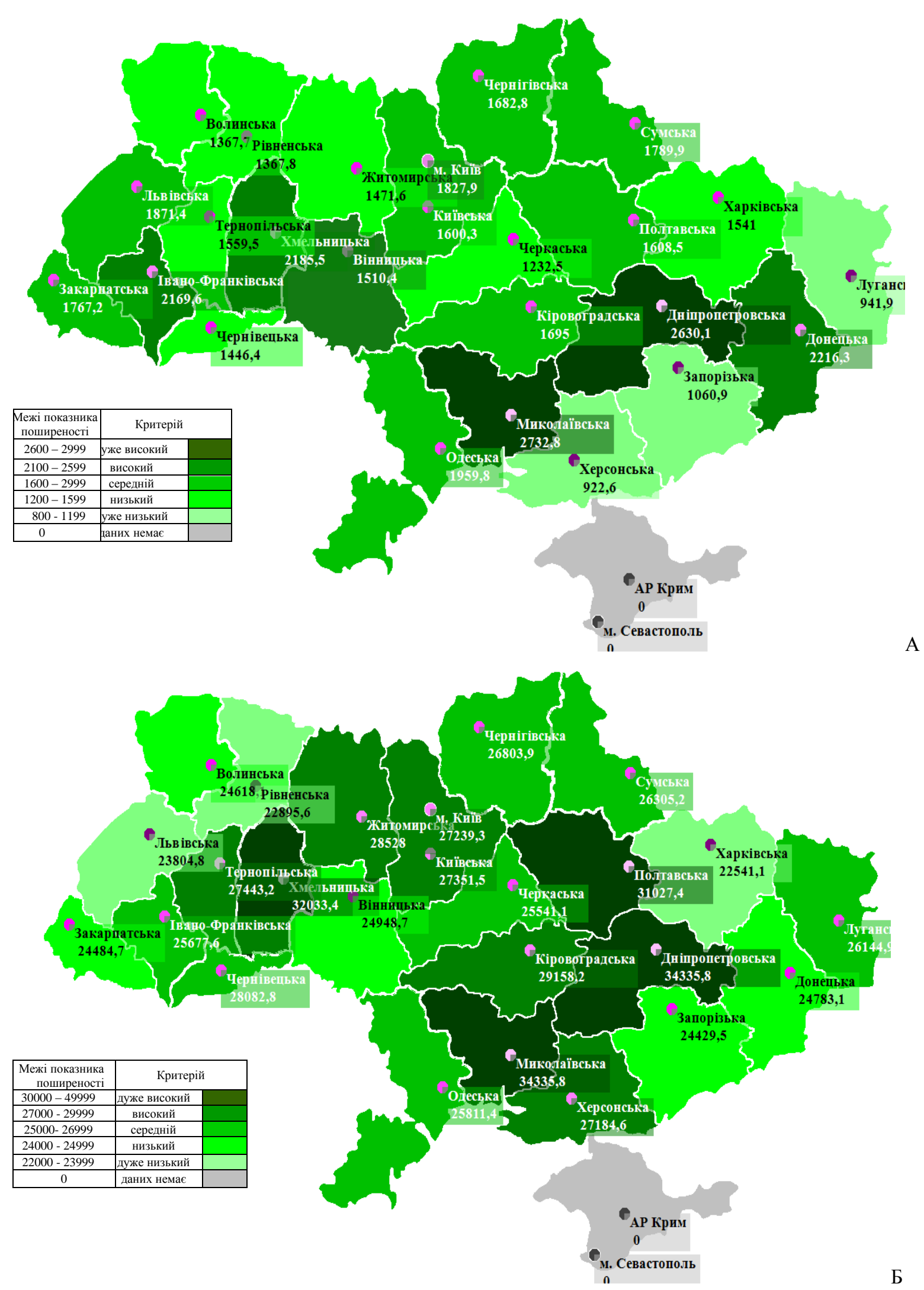

Картограма. Показники рівнів поширеності (на 100 тисяч мешканців) первинної (А) та загальної (Б) захворюваності на ГХ серед населення адміністративних територій України в 2017 році

( $\mathrm{P}_{\text {пер }}=1559,5 / 100$ тис. $)$ Харківської ( $\mathrm{P}_{\text {пер }}=1541 \%$ оооо $)$, Вінницької $\quad\left(\mathrm{P}_{\text {пер }}=1510,4 / 100000\right)$, Житомирської
$\left(\mathrm{P}_{\text {пер }}=1471,6 \%\right.$ \%ооо $)$, Чернівецької $\quad\left(\mathrm{P}_{\text {пер }}=1446,4 / 100\right.$ тис.), Рівненської ( $\mathrm{P}_{\text {пер }}=1367,8 \%$ ооо $)$, Волинської 


\section{Проблеми охорони здоров'я}

$\left(\mathrm{P}_{\text {пер }}=1367,7 / 100000\right)$ та Черкаської $\left(\mathrm{P}_{\text {пер }}=1232,5 \%\right.$ оооо $)$ областей.

Під встановлений четвертий критерій $\left(\mathrm{P}_{\text {заг }}=24000\right.$ $24999 \%$ оооо) підпадає загальне число рівня реєстрованих випадків усіх форм даної хвороби встановлено в п'яти областях ( $\left.\mathrm{P}_{\text {стр }}=18,5 \%\right)$ : Вінницькій $\left(\mathrm{P}_{\text {заг }}=24948,7 / 100000\right), \quad$ Донецькій $\left(\mathrm{P}_{\text {заг }}=24783,1 \%\right.$ оооо $), \quad$ Волинській $\quad\left(\mathrm{P}_{\text {заг }}=24618,1 / 100\right.$ тис.), Закарпатській ( $\mathrm{P}_{\text {заг }}=24484,7 \%$ оооо $)$ та Запорізькій $\left(\mathrm{P}_{\text {заг }}=24429,5 / 100000\right)$.

3'ясовано, що найнижчий рівень $\left(\mathrm{P}_{\text {пер }}=800-1199\right.$ \%ооо - п'ятий, первинної розповсюдженості гіпертонічної хвороби в 2017 році зафіксовано серед

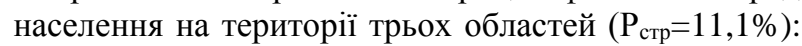
Запорізької, де показник поширеності сягав $\mathrm{P}_{\text {пер }}=1060,9$ випадка на 100 тисяч населення даного регіону; Луганської $-\mathrm{P}_{\text {пер }}=941,9 \%$ оооо та Херсонської $-\mathrm{P}_{\text {пер }}=922,6 / 100$ тис.

Аналіз числових величин показників поширеності загальної захворюваності на ГХ серед мешканців Львівської $\quad\left(\mathrm{P}_{\text {заг }}=23804,8 / 100\right.$ тис. $)$, Рівненської ( $\mathrm{P}_{\text {заг }}=22895,6 \%$ \%ооо $)$, а також Харківської $\left(\mathrm{P}_{\text {заг }}=22541,1 / 100000\right) \quad$ областей $\quad\left(\mathrm{P}_{\text {стр }}=11,1 \%\right)$ переконливо засвідчує також про п'ятий найменший критерій $\quad\left(\mathrm{P}_{3_{\mathrm{ar}}}=22000-23999 \%\right.$ оооо $)$ розповсюдження даної патології [I10-I15;I20X7I25X7; I60;X7-I69X7] на адміністративних територіях України.

Вагомим, у цьому є говорити і про те, що 3 причини тимчасово окупованих адміністративних територій Луганської та Донецької областей біостатистичні дані про рівень поширення захворюваності на ГХ за іiі видами серед даної когорти населення в 2017 році $є$ неповними, а 3 анексованих міста Севастополя та АР Крим аналізовані біостатистичні дані відсутні. Проте навіть така ситуація в контексті наявного адміністративно-територіально поділу не вносить суттєвих змін у процес наукового встановлення та обгрунтування особливостей щодо поширеності гіпертонічної хвороби серед населення адміністративних територій України. У процесі виконання наукової роботи досліджувалися також i особливості у стані захворюваності на гіпертонічну хворобу населення країни в контексті встановлених історико-географічних регіонів України [12], згідно зі встановленими усередненими $(\mathrm{m})$ даними по кожному рігіоні України як за кількісним виразом (абс. дані), так і показниками структури (\%) та поширеності (\%ооо).

Вмотивовано доведено, що перше оціночне місце, згідно з отриманими біостатистичними даними по кожному рігіоні України (див. дані таблиці), у стані первинної $\quad\left(\sum \mathrm{n}=191023 ; \quad \mathrm{P}=28,0 \pm 1,6 \%, \quad\right.$ при $\mathrm{P}=1810,3 / 100000) \quad$ та загальної $\quad\left(\sum \mathrm{n}=2947296\right.$; $\mathrm{P}=28,4 \pm 1,6 \% ; \quad \mathrm{P}=29507,4$ \%ооо) захворюваності на гіпертонічну хворобу відведено мешканцям Центрального регіону України (Вінницька, Дніпропетровська, Кіровоградська, Полтавська,
Черкаська, Хмельницька області ).

Другу позицію в цьому рейтингу як за показниками первинної, так і загальної захворюваності на ГХ 3 їх відповідним значенням (таблиця) посідає населення Західного, третій ранг відведено мешканцям Північного , а четверте місце обіймають жителі Південного регіонів.

І останнє - п'яте місце в даному рейтингу посідає населення, котре мешкає у Східному регіоні країни (Харківська, Донецька та Луганська області) як за даними вперше діагностованих випадків гіпертонічної хвороби $\left(\sum \mathrm{n}=91148 ; \mathrm{P}=13,4 \pm 3,4 \%\right.$; $\mathrm{P}=1566,4 \%$ ооо), так і показниками загальної захворюваності на ГХ ( $\sum \mathrm{n}=1271770 ; \mathrm{P}=12,2 \pm 3,7 \%$; $\mathrm{P}=24489,7 / 100000)$.

\section{Висновки}

1. Відповідно до даних рейтингової оцінки показника поширеності на адміністративних територіях України встановлено :

1.1. Серед уперше зареєстрованих випадків усіх форм гіпертонічної хвороби найвищий рівень поширеності первинної захворюваності на гіпертонічну хворобу і перше рейтингове місце $\left(\mathrm{P}_{\text {пер }}=2600-2999 \%\right.$ оооо $) є$ характерним для жителів Миколаївської ( $\mathrm{P}_{\text {пер }}=2732,8 \quad$ \%ооо $)$ та Дніпропетровської ( $\mathrm{P}_{\text {пер}}=2630,1 / 100$ тис.) областей, тоді як найнижчий ступінь розповсюдження даної патології та п'яте оціночне місце ( $\mathrm{P}_{\text {пер}}=800-1199$ \%ооо $) є$ притаманним для мешканців Запорізької $\quad\left(\mathrm{P}_{\text {пер }}=1060,9 / 100000\right)$, Луганської $\left(\mathrm{P}_{\text {пер }}=941,9 \%\right.$ таоо Херсонської $\left(\mathrm{P}_{\text {пер }}=922,6 / 100\right.$ тис. $)$ областей.

1.2. Перше рейтингове місце - як найвищий щабель поширення загальної захворюваності на гіпертонічну хворобу ( $\mathrm{P}_{\text {заг }}=30000-49999 \%$ \%ооо $)$ в властивим для населення Дніпропетровської ( $\mathrm{P}_{\text {заг }}=34335,8 / 100$ тис.), Хмельницької $\left(\mathrm{P}_{\text {заг }}=32033,4 \%\right.$ оооо $), \quad$ Полтавської $\quad\left(\mathrm{P}_{\text {заг }}=31027,4 \%\right.$ оооо $) \quad$ та Миколаївської $\left(\mathrm{P}_{\text {заг }}=34335,8 \%\right.$ оооо $)$ областей, а п'ятий найжчий ступінь поширеності даного виду захворюваності на гіпертонічну хворобу ( $\mathrm{P}_{\text {заг }}=22000-23999 \%$ встановлено для мешканців Львівської ( $\mathrm{P}_{\text {заг }}=23804,8 / 100$ тис.), Рівненської (Рзаг=22895,6 \%оо) та Харківської $\left(\mathrm{P}_{\text {заг }}=22541,1 / 100000\right)$ адміністративних територій України.

2. Визначено, що перше оціночне місце, згідно 3 отриманими регіональними біостатистичними даними у стані первинної $\left(\sum \mathrm{n}=191023 ; \quad \mathrm{P}=28,0 \pm 1,6 \%\right.$, при $\mathrm{P}=1810,3 / 100000)$ та загальної ( $\sum \mathrm{n}=2947296 ; \mathrm{P}=28,4 \pm 1,6 \%$; $\mathrm{P}=29507,4 \%$ ооо) захворюваності на гіпертонічну хворобу відведено мешканцям Центрального регіону України (Вінницька, Дніпропетровська, Кіровоградська, Полтавська, Черкаська, Хмельницька області), тоді як останнє - п’яте місце в даному рейтингу посідає населення, котре мешкає у Східному регіоні країни (Харківська, Донецька та Луганська області) як за даними вперше діагностованих випадків гіпертонічної хвороби $\left(\sum \mathrm{n}=91148\right.$; $\mathrm{P}=13,4 \pm 3,4 \% ; \mathrm{P}=1566,4$ \%ооо), так і показниками загальної захворюваності на гіпертонічну хворобу $\left(\sum \mathrm{n}=1271770\right.$; $\mathrm{P}=12,2 \pm 3,7 \% ; \mathrm{P}=24489,7 / 100000)$.

3. Отримані результати переконливо засвідчують, що як первинна, так і загальна захворюваність на гіпертонічну хворобу є складною медико-соціальною проблемою серед населення України як в усіх адміністративних терироріях, так i регіонах країни i потребує на рівні держави напрацювання реальних та дієвих профілактичних шляхів вчасної мінімізації ризиків у їі виникненні в конкретної 
Problems of medical care

\begin{tabular}{|c|c|c|c|c|c|c|c|}
\hline & & $\begin{array}{r}\text { ональні особливості загаль } \\
\text { І.15,I.20;X.7-I.2 }\end{array}$ & $\begin{array}{l}\text { ої та первинної зะ } \\
\text { X.7,I.60;X.7-I.69. }\end{array}$ & $\begin{array}{l}\text { орюваності н } \\
\text { | серед населе } \\
\end{array}$ & $\begin{array}{l}\text { гіпертонічну хв } \\
\text { Іня України в } 21 \\
\end{array}$ & $\begin{array}{l}\text { y (всі форми) [I. } \\
\text { оці }\end{array}$ & $\begin{array}{l}\text { Таблиця } \\
\mathbf{1 0 -}\end{array}$ \\
\hline \multirow{2}{*}{ 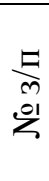 } & \multirow{2}{*}{. } & \multirow{2}{*}{$\begin{array}{c}\text { Назви } \\
\text { областей та міст } \\
\text { центрального } \\
\text { підпорядкування }\end{array}$} & \multicolumn{2}{|c|}{$\begin{array}{c}\text { Зареєстровано } \\
\text { захворювань на ГХ всього }\end{array}$} & \multicolumn{2}{|c|}{$\begin{array}{c}\text { в т.ч. } 3 \text { діагнозом ГХ, } \\
\text { встановленим вперше в житті }\end{array}$} & \multirow{2}{*}{$\begin{array}{r}\text { Індекс } \\
\text { накопи } \\
\text { чення }\end{array}$} \\
\hline & & & (абс. дані) & $\begin{array}{l}\text { на } 100 \text { тис. } \\
\text { населення }\end{array}$ & (абс. дані) & $\begin{array}{l}\text { на } 100 \text { тис. } \\
\text { населення }\end{array}$ & \\
\hline 1. & 2. & 3. & 4. & 5. & 6. & 7. & 8. \\
\hline 1. & & Україна & $\sum_{\Pi}=10388376$ & 24492,3 & 682740 & 1609,7 & 15,2 \\
\hline \multirow{10}{*}{2.} & \multirow{10}{*}{ 罢 } & Львівська & 598848 & 23804,8 & 47078 & 1871,4 & 12,7 \\
\hline & & Івано-Франківська & 353629 & 25677,6 & 29879 & 2169,6 & 11,8 \\
\hline & & Тернопільська & 289784 & 27443,2 & 16467 & 1559,5 & 17,6 \\
\hline & & Волинська & 255592 & 24618,1 & 14200 & 1367,7 & 18,0 \\
\hline & & Рівненська & 265979 & 22895,6 & 15890 & 1367,8 & 16,7 \\
\hline & & Чернівецька & 254165 & 28082,8 & 13091 & 1446,4 & 19,4 \\
\hline & & Закарпатська & 307514 & 24484,7 & 22195 & 1767,2 & 13,9 \\
\hline & & Узагальнені дані & $\sum \mathrm{n}=2325511$ & \multirow{3}{*}{$\mathrm{P}=25286,7$} & $\sum n=158800$ & \multirow{3}{*}{$\mathrm{P}=1649,9$} & \multirow{3}{*}{14,6} \\
\hline & & по Західному регіону & $\mathrm{P}=22,4 \pm 2,0 \%$ & & $\mathrm{P}=23,2 \pm 1,9 \%$ & & \\
\hline & & Рейтингове місце & II & & II & & \\
\hline \multirow{6}{*}{3.} & \multirow{6}{*}{ 罢 } & Харківська & 605354 & 22541,1 & 41384 & 1541 & 14,6 \\
\hline & & Донецька & 482280 & 24783,1 & 43130 & 2216,3 & 11,2 \\
\hline & & Луганська & 184136 & 26144,9 & 6634 & 941,9 & 27,8 \\
\hline & & Узагальнені дані & $\sum \mathrm{n}=1271770$ & \multirow{3}{*}{$\mathrm{P}=24489,7$} & $\sum \mathrm{n}=91148$ & \multirow{3}{*}{$P=1566,4$} & \multirow{3}{*}{14,0} \\
\hline & & по Східному регіону & $\mathrm{P}=12,2 \pm 3,7 \%$ & & $\mathrm{P}=13,4 \pm 3,4 \%$ & & \\
\hline & & Рейтингове місце & $\mathrm{V}$ & & $\mathrm{V}$ & & \\
\hline \multirow{9}{*}{4.} & \multirow{9}{*}{ 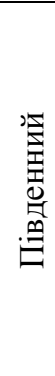 } & Запорізька & 424756 & 24429,5 & 18445 & 1060,9 & 23,0 \\
\hline & & Херсонська & 286585 & 27184,6 & 9726 & 922,6 & 29,5 \\
\hline & & Одеська & 613139 & 25811,4 & 46553 & 1959,8 & 13,2 \\
\hline & & Миколаївська & 342010 & 29755,2 & 31411 & 2732,8 & 10,9 \\
\hline & & АР Крим & 0 & 0 & 0 & 0 & - \\
\hline & & м. Севастополь & 0 & 0 & 0 & 0 & - \\
\hline & & Узагальнені дані & $\sum \mathrm{n}=1666490$ & \multirow{3}{*}{$\mathrm{P}=26795,5$} & $\sum \mathrm{n}=106135$ & \multirow{3}{*}{$\mathrm{P}=1669,1$} & \multirow{3}{*}{15,7} \\
\hline & & по Південному регіону & $\mathrm{P}=16,0 \pm 2,8 \%$ & & $\mathrm{P}=15,5 \pm 2,9 \%$ & & \\
\hline & & Рейтингове місце & IV & & IV & & \\
\hline \multirow{8}{*}{5.} & & Житомирська & 354104 & 28528 & 18266 & 1471,6 & 19,4 \\
\hline & & Київська & 472824 & 27351,5 & 27665 & 1600,3 & 17,1 \\
\hline & $\stackrel{\nu}{\Xi}$ & Чернігівська & 274705 & 26803,9 & 17246 & 1682,8 & 15,9 \\
\hline &.$\Xi$ & Сумська & 289972 & 26305,2 & 19731 & 1789,9 & 14,7 \\
\hline & 居 & м. Київ & 785704 & 27239,3 & 52726 & 1827,9 & 14,9 \\
\hline & 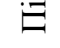 & Узагальнені дані & $\sum \mathrm{n}=2177309$ & & $\sum n=135634$ & & \\
\hline & & по Північному регіону & $\mathrm{P}=21,0 \pm 2,1 \%$ & $\mathrm{P}=27245,6$ & $\mathrm{P}=20,0 \pm 2,2 \%$ & $\mathrm{P}=1674,5$ & 16,1 \\
\hline & & Рейтингове місце & III & & III & & \\
\hline & & Вінницька & 395006 & 24948,7 & 23913 & 1510,4 & 16,5 \\
\hline & & Дніпропетровська & 1108050 & 34335,8 & 84875 & 2630,1 & 13,1 \\
\hline & & Кіровоградська & 279727 & 29158,2 & 16261 & 1695 & 17,2 \\
\hline & 疍 & Полтавська & 440275 & 31027,4 & 22824 & 1608,5 & 19,3 \\
\hline 6. & క్త్రి & Черкаська & 313537 & 25541,1 & 15130 & 1232,5 & 20,7 \\
\hline 0. & 密 & Хмельницька & 410701 & 32033,4 & 28020 & 2185,5 & 14,7 \\
\hline & $\stackrel{\vec{\theta}}{\Xi}$ & Узагальнені дані & $\sum \mathrm{n}=2947296$ & & $\sum \mathrm{n}=191023$ & & \\
\hline & & по Центральному регіону & $\mathrm{P}=28,4 \pm 1,6 \%$ & $P=29507,4$ & $\mathrm{P}=28,0 \pm 1,6 \%$ & $\mathrm{P}=1810,3$ & 15,4 \\
\hline & & Рейтингове місце & $\mathrm{I}$ & & $\mathrm{I}$ & & \\
\hline
\end{tabular}

людини, що матиме позитивний і безпосередній вплив на стан громадського здоров'я населення та економіку України.

Перспективи подальших досліджень. У подальших наукових роботах вивчатимуться фактори ризику серед певних популяцій 3 метою мінімізації захворюваності населення на гіпертонічну хворобу.

Список літератури

1. Всемирный атлас профилактики сердечнососудистых заболеваний и борьбы с ними. Политика, стратегия и меры борьбы ВОЗ, Всемирная федерация 


\section{Проблеми охорони здоров'я}

сердца, Всемирная организация инфаркта [Інтернет]. 2013 [Цитовано 2020 Трав. 12]; 163 с. Доступно на https://www.who.int/cardiovascular_diseases/ publications/ atlas_cvd/ru/.

2. Оганов РГ, Кухарчук ВВ, Бритов АН, редактор. Доклад Комитета экспертов ВОЗ. Москва: Гос. НИЦ проф. мед. МЗ РФ; 1997. 139 с.

3. Гипертония. Информационный бюллетень ВО3 [Інтернет]. 13 сентября 2019 [Цитовано 2020 Трав. 27]. Доступно: https://www.who.int/ru/news-room/fact-sheets/ detail/ hypertension.

4. Сердечно-сосудистые заболевания. Информационный бюллетень ВОЗ [Інтернет]. 17 мая 2017 [Цитовано 2020 Трав. 27]. Доступно: https://www.who.int/ru/newsroom/fact-sheets/detail/ cardiovascular-diseases-(cvds).

5. 2018 ЕОК/ЕОАГ Рекомендации по лечению больных c артериальной гипертензией. Российский кардиологический журнал [Інтернет]. 2018 [Цитовано 2020 Трав 27]; 23(12);152. Доступно: http://webmed. irkutsk.ru/ doc/pdf/hypertesc.pdf.

6. Рудень ВВ, Барна ВА, Кудря АВ. Про тенденції у розвитку неінфекційних хвороб серед населення незалежної України та їх вікова характеристика Львівський медичний часопис. Acta Medica Leopoliensia. 2019;2-3(25):82-90. [Internet] [Цитовано 2020 Трав 27]. Доступно: http://www.aml.lviv.ua/redakce/index.php? Clanek $=3652 \&$ slozka $=1303 \&$ xsekce $=1531 \&$ lanG $=$ uk \&xuser $=$ DOI: 10.25040/aml2019.02.082.

7. Рудень ВВ. Дефініція місця класу хвороб системи кровообігу та їх структурна своєрідність серед населення України. Львівський медичний часопис. Acta Medica Leopoliensia. 2020;1(26):53-61. [Інтернет] [Цитовано 2020 Трав 27]. Доступно: http://www.aml.lviv.uaredakce/ index.php?clanek $=3834 \&$ slozka $=1303 \&$ xsekce $=1531 \&$ lanG $=$ uk\&xuser= DOI: https://doi.org/10.25040/aml2020.01.053.

8. Лашкул ЗВ. Особливості епідеміології артеріальної гіпертензії та їі ускладнень на регіональному рівні з 1999 по 2013 роки. Сучасні медичні технології. 2014;2:143-41. [Інтернет] [Цитовано 2020 Трав 27]. Доступно: http://www.zmapo-journal.com.ua/wp-content/uploads/ 2014. pdf.

9. Демографічна та соціальна статистика: населення України. Державна служба статистики України. Київ: [Інтернет]. 1990-2018 [Цитовано 2020 Берез. 20]. Доступно: http://www.ukrstat.gov.ua/.

10. Показники здоров'я населення та використання ресурсів охорони здоров'я в Україні за 1993-2018 роки. ДЗ «Центр медичної статистики МО3 України». Київ. [Інтернет] [Цитовано 2020 Трав 20]. Доступно: http://medstat.gov.ua/ukr/statdov.html.

11. Ковбасюк ЮВ, Орлатий МК, редактор. Адміністративно-територіальний устрій країн Європейського Союзу: навч. посіб. Київ: НАДУ; 2015. 628 c.

12. Верменич ЯВ. Історико-географічний регіон. Енциклопедія історії України: НАН України. Інститут історії України. Київ: В-во "Наукова думка"; 2005. [Інтернет] [Цитовано 2020 Трав 20]; Т.3: Е-Й: 672 с. Доступно: http://www.history.org.ua/?termin=Istoryko_ geograf_region.

\section{References}

1. Vsemirnyy atlas profilaktiki serdechno-sosudistykh zabolevaniy i bor'by s nimi. Politika, strategiya i mery bor'by VOZ, Vsemirnaya federatsiya serdtsa, Vsemirnaya organizatsiya infarkta [World Atlas of Cardiovascular Disease
Prevention and Control. WHO policies, strategies and measures. World Heart Federation. World Heart Attack Organization] [Internet]. 2013 [cited 2020 May 12]. Available from: https://www.who.int/cardiovascular_diseases/ publications /atlas_cvd/ru/ (in Russian).

2. Oganov RG, Kukharchuk VV, Britov AN, editors. Doklad Komiteta ekspertov VOZ [Report of the WHO Expert Committee]. Moskow: Gos. NITs prof. med. MZ RF RF; 1997. 139 p. (in Russian).

3. Gipertoniya [Hypertension]. Informatsionnyy byulleten' VOZ [Internet]. 13 sentjabrja 2019 [cited 2020 May 27]. Available from: https://www.who.int/ru/news-room/factsheets/detail/ hypertension. (in Russian).

4. Serdechno-sosudistye zabolevaniya [Cardiovascular diseases]. Informatsionnyy byulleten' VOZ [Internet]. 17 maya 2017 [cited 2020 May 27]. Available from: https://www.who.int/ru/news-room/factsheets/detail/cardiovascular-diseases-(cvds). (in Russian).

5. 2018 EOK/EOAG Rekomendatsii po lecheniyu bol'nykh s arterial'noy gipertenziey [2018 EOK/EOAГ Recommendations for the treatment of patients with arterial hypertension]. Rossiyskiy kardiologicheskiy zhurnal. 2018;23(12);152. [Internet] [cited 2020 May 27]. Available from: http://webmed. irkutsk.ru/doc/pdf/hypertesc.pdf. (in Russian).

6. Ruden' VV, Barna VA, Kudria AV. Pro tendentsii u rozvytku neinfektsiinykh khvorob sered naselennia nezalezhnoi Ukrainy ta yikh vikova kharakterystyka [On trends in the development of non-communicable diseases among the population of independent Ukraine and their age characteristics]. L'vivs'kyi medychnyi chasopys. Acta Medica Leopoliensia. 2019;2-3(25):82-90. [Internet] [cited 2020 May 27]. Available from: http://www.aml.lviv.ua/redakce/ index.php?Clanek $=3652 \&$ slozka $=1303 \&$ xsekce $=1531 \&$ lan $\mathrm{G}=\mathrm{uk} \&$ xuser=DOI:10.25040/aml2019.02.082. (in Ukrainian).

7. Ruden' VV. Definitsiia mistsia klasu khvorob systemy krovoobihu ta yikh strukturna svoieridnist' sered naselennia Ukrainy [Definition of the place of the class of diseases of the circulatory system and their structural originality among the population of Ukraine]. L'vivs'kyi medychnyi chasopys. Acta Medica Leopoliensia. 2020;1(26):53-61. [Internet] [cited 2020 May 27]. Available from: http://www.aml.lviv.uaredakce /index.php?clanek $=3834 \&$ slozka $=1303 \&$ xsekce $=1531 \&$ lanG $=$ uk\&xuser= DOI: https://doi.org/10.25040/aml2020.01.053 (in Ukrainian).

8. Lashkul ZV. Osoblyvosti epidemiolohii arterial'noi hipertenzii ta yii usklad-nen' na rehional'nomu rivni z 1999 po 2013 roky [Features of the epidemiology of arterial hypertension and its complications at the regional level from 1999 to 2013]. Suchasni medychni tekhnolohii. 2014;2:143-41. [Internet] [cited 2020 May 27]. Available from: http://www.zmapo-journal.com.ua/wp-content/uploads/ 2014.pdf. (in Ukrainian).

9. Demohrafichna ta sotsial'na statystyka: naselennia Ukrainy. Derzhavna sluzhba statystyky Ukrainy [Demographic and social statistics: population of Ukraine. State Statistics Service of Ukraine]. Kyiv: [Internet]. 1990-2018 [cited 2020 March 20]. Available from: http://www.ukrstat.gov.ua. (in Ukrainian).

10. Pokaznyky zdorov'ia naselennia ta vykorystannia resursiv okhorony zdorov'ia v Ukraini za 1993-2018 roky. DZ «Tsentr medychnoi statystyky MOZ Ukrainy» [Indicators of public health and use of health resources in Ukraine for 1993 2018. State Institution "Center for Medical Statistics of the Ministry of Health of Ukraine"]. Kyiv. [Internet] [cited 2020 May 20]. Available from: http://medstat.gov.ua/ukr/ 


\section{Problems of medical care}

statdov.html. (in Ukrainian).

11. Kovbasiuk YuV, Orlatyi MK, editors. Administratyvno-terytorial'nyi ustrii krain Yevropeis'koho Soiuzu [Administrative and territorial organization of the European Union]. Kyiv: NADU; 2015. 628 p. (in Ukrainian).

12. Vermenych YaV. Istoryko-heohrafichnyi rehion.
Entsyklopediia istorii Ukrainy: NAN Ukrainy. Instytut istorii Ukrainy. Kyiv: V-vo "Naukova dumka"; 2005. [Internet] [Citen 2020 May 20]; T.3: E-I: 672 p. Available from: http://www.history.org.ua/?termin=Istoryko_ geograf_region. (in Ukrainian).

\section{Відомості про автора}

Рудень Василь Володимирович - заслужений лікар України, академік Національної академії наук вищої освіти України, академік української Міжнародної академії профілактичної медицини Наукового товариства імені Шевченка (Україна), дійсний член Нью-Йоркської академії наук (США), академік Міжнародної академії наук вищої освіти (Лондон, Великобританія), доктор медичних наук, професор Львівського національного медичного університету імені Данила Галицького; 79010 м. Львів, вул. Пекарська, 69.

\section{Сведения об авторе}

Рудень Василий Владимирович - заслуженный врач Украины, академик Национальной академии наук высшего образования Украины, академик украинской Международной академии профилактической медицины Научного общества имени Шевченко (Украина), действительный член Нью-Йоркской академии наук (США), академик Международной академии наук высшего образования (Лондон, Великобритания), доктор медицинских наук, профессор Львовского национального медицинского университета имени Данила Галицкого; 79010 г. Львов, ул. Пекарская, 69.

\section{Information about the author}

Ruden` Vasyl Volodymyrovych - Honored Doctor of Ukraine, Academician of the National Academy of Higher Education Sciences of Ukraine, Academician of the Ukrainian International Academy of Preventive Medicine of the Shevchenko Scientific Society (Ukraine), full member of the New York Academy of Sciences (USA), Academician of the International Academy of Sciences and Higher Education (London, Great Britain), Doctor of Medical Sciences, Professor of Danylo Halytsky Lviv National Medical University; 79010, 69 Pekarska Str, Lviv.

Надійшла до редакції 09.06.20

Рецензент - доц. Навчук I.В.

(C) В.В. Рудень, 2020 